\title{
SACRAL INSUFFICIENCY FRACTURES - A COMMONLY OVERLOOKED CAUSE OF LOW BACK AND PELVIC PAIN; A CASE REPORT AND LITERATURE REVIEW
}

\author{
PRIJELOM SAKRUMA U OSLABLJENOJ KOSTI \\ - ČESTO NEPREPOZNAT UZROK KRIŽOBOLJE I BOLI U ZDJELICI \\ - PRIKAZ BOLESNICE S PREGLEDOM LITERATURE
}

\author{
Danijela Veljković Vujaklija ${ }^{1}$, Tea Schnurrer Luke-Vrbanić ${ }^{2}$ \\ ${ }^{1}$ Department of Radiology, Clinical Hospital Centre Rijeka, Rijeka / Klinički zavod za radiologiju, KBC Rijeka, Rijeka; \\ ${ }^{2}$ Department of Physical and Rehabilitation Medicine, Clinical Hospital Centre Rijeka, Rijeka \\ / Zavod za fizikalnu i rehabilitacijsku medicinu, KBC Rijeka, Rijeka
}

\author{
Corresponding author / Adresa autora za dopisivanje: \\ Prof. dr. sc. Tea Schnurrer-Luke-Vrbanić \\ Department of Physical and Rehabilitation Medicine / Zavod za fizikalnu i rehabilitacijsku medicinu \\ Clinical Hospital Centre Rijeka / KBC Rijeka \\ Krešimirova 42, 51000 Rijeka
}

Croatia / Hrvatska

Phone / tel.: +385/98/415919

E-mail / e-pošta: fizikalna@kbc-rijeka.hr

Received / Primljeno: May 20, 2020 / 20. svibnja 2020. Accepted / Prihvaćeno: October 30, 2020 / 30. listopada 2020.

\section{Abstract}

Sacral stress fractures are divided into fatigue fractures and insufficiency fractures. Fatigue fractures occur in a normal bone exposed to abnormal or repetitive stresses, whereas insufficiency fractures occur in weakened bones under normal stress and with no underlying trauma.

Sacral insufficiency fractures are often overlooked causes of nonspecific lumbosacral back pain, especially in elderly women with underlying osteoporosis. In addition to old age and postmenopausal osteoporosis, other conditions which reduce bone mineral density and present risk factors for the occurrence of insufficiency fractures include: long-term glucocorticoid and bisphosphonates therapy, long-term vitamin D insufficiency and osteomalacia, renal osteodystrophy, primary hyperparathyroidism, Paget's disease, long-term immobilisation and radiotherapy for the treatment of malignant diseases. There are no typical clinical signs to suggest sacral stress fracture. These fractures are often associated with degenerative diseases of the spine and intervertebral disc, and they are often accompanied by pre-existing osteoporotic vertebral compression fractures. Plain radiographs of the spine and pelvis, which are the first step in diagnostic imaging, are usually non-diagnostic when it comes to sacral fractures. Due to radicular pain symptoms, magnetic resonance imaging of the lumbosacral spine is the next step in diagnosis, in which sacral fractures are often revealed as accidental findings. In this paper, we shall present a case of an elderly patient with multiple comorbidities and multiple risk factors, in whose case physical therapy did not prove to be effective. During diagnostic testing, a subsequent MRI showed an accidental finding confirming the sacral fracture. Furthermore, we shall highlight the importance of early detection of sacral stress fracture in high-risk patients, in order to avoid unnecessary, and sometimes invasive, diagnostic procedures and to reduce the possibility of possible complications. The imaging method of choice for the diagnosis of sacral stress fractures is MRI.

KEY WORDS: Fractures, stress - complications, diagnostic imaging, etiology; Low back pain - etiology; Pelvic pain - etiology; Sacrum - injuries, surgery; Spinal fractures - complications, diagnostic imaging, etiology; Magnetic resonance imaging; Vertebroplasty - methods

\section{SAŽETAK}

Stresne prijelome (engl. stress fractures) možemo podijeliti na prijelome zamora ili stresne prijelome u užem smislu (engl. fatigue fractures) i na prijelome u oslabljenoj kosti (engl. insufficiency fractures). Prijelomi zamora nastaju 
u zdravoj kosti zbog dugotrajnog ponavljanja neprimjerenog opterećenja, dok prijelomi u oslabljenoj kosti nastaju spontano, odnosno bez prethodne traume. Prijelomi sakruma u oslabljenoj kosti često su neprepoznat uzrok križobolje i boli u zdjelici, posebice u žena starije dobi s osteoporozom.

Osim starije dobi i postmenopauzalne osteoporoze, rizični čimbenici za prijelom u oslabljenoj kosti jesu dugotrajna terapija glukokortikoidima i bisfosfonatima, dugotrajan teži nedostatak vitamina D i osteomalacija, renalna osteodistrofija, primarni hiperparatiroidizam, Pagetova bolest, dugotrajna nepokretnost i radioterapija zbog maligne bolesti.

Specifični klinički znakovi stresnog prijeloma sakruma ne postoje. Ovakvi prijelomi često su udruženi s degenerativnim promjenama kralježnice i intervertebralnog diska, a često su prisutni i osteoporotični prijelomi kralježaka. Na standardnim radiogramima kralježnice i zdjelice, koji su prvi korak u slikovnoj dijagnostičkoj obradi, prijelomi sakruma najčešće se ne uočavaju. Zbog često prisutnih radikularnih simptoma sljedeći dijagnostički korak jest magnetska rezonancija lumbosakralne kralježnice na kojoj su prijelomi sakruma najčešće slučajan nalaz. Prikazujemo bolesnicu s multiplim komorbiditetima i višestrukim čimbenicima rizika kod koje je zbog prolongirane križobolje provedena fizikalna terapija s nezadovoljavajućim učinkom. Tijekom obrade učinjena je magnetska rezonancija gdje je kao slučajan nalaz potvrđen prijelom sakruma. Ističemo važnost ranog prepoznavanja rizičnih skupina pacijenata čime se postiže izbjegavanje suvišnih, katkad i invazivnih dijagnostičkih postupaka. Slikovna metoda izbora za dijagnozu stresnog prijeloma sakruma jest magnetska rezonancija.

KLJUČNE RIJEČr: Prijelomi zamora - dijagnostički slikovni prikaz, etiologija, komplikacije; Križobolja - etiologija; Zdjelična bol - etiologija; Sakrum - ozljede, kirurgija; Prijelomi kralješnice - dijagnostički slikovni prikaz, etiologija, komplikacije; Magnetska rezonancija; Vertebroplastika - metode

\section{INTRODUCTION}

Sacral stress fractures are divided into fatigue fractures and insufficiency fractures $(1-3)$. It is crucial to note the difference between the two, due to the different pathophysiological processes they are based upon and the different approaches to their treatment.

Fatigue fractures occur due to prolonged repetition of abnormal stresses on normal and healthy bone (usually related to sports or one's profession) or normal stresses in abnormal biomechanics (e.g., coxa vara). In both of the aforementioned cases, bone damage occurs which exceeds the bone's ability to restore itself. Following that, there is an increased osteoclastic activity and cortical bone resorption and, finally, the occurrence of fracture. Fatigue fractures most often occur in lower extremities $(4,5)$.

Insufficiency fractures occur under normal stresses, are more common in the elderly, they are usually associated with osteoporosis, and typically occur in and around the pelvic bones (6). In addition to old age and osteoporosis, other risk factors for the occurrence of insufficiency fractures include: long-term glucocorticoid and bisphosphonates therapy, long-term vitamin $\mathrm{D}$ insufficiency and osteomalacia, renal osteodystrophy, primary hyperparathyroidism, Paget's disease, long-term immobilisation and radiotherapy for the treatment of malignant diseases $(6,7)$.

Sacral insufficiency fractures which occur spontaneously, with no underlying trauma, are often overlooked causes of nonspecific lumbosacral back pain in old age, especially in elderly women with underlying osteoporosis (6). There are no typical clinical signs to suggest sacral stress fracture, which is why the diagnosis is

\section{UVOD}

Stresne prijelome (engl. stress fractures) možemo podijeliti na prijelome zamora ili stresne prijelome u užem smislu (engl. fatigue fractures) i na prijelome u oslabljenoj kosti (engl. insufficiency fractures) $(1-3)$. Njihovo je razlikovanje nužno s obzirom na različit patofiziološki proces u podlozi i različit pristup liječenju.

Prijelomi zamora nastaju u zdravoj kosti zbog dugotrajnog ponavljanja neprimjerenog opterećenja (najčešće sportskog ili profesionalnoga) ili pri primjerenim opterećenjima u poremećenim biomehaničkim odnosima (npr., coxa vara). U oba slučaja dolazi do oštećenja kosti koje nadvlada njezine reparacijske sposobnosti. Tada dolazi do pojačane osteoklastične aktivnosti i resorpcije kortikalne kosti te, na kraju, do prijeloma. Prijelomi zamora najčešće nastaju na donjim ekstremitetima $(4,5)$.

Prijelomi u oslabljenoj kosti nastaju pri uobičajenim opterećenjima, češći su u starijih osoba, obično su povezani s osteoporozom te tipično nastaju na kostima zdjelice i oko nje (6). Osim starije dobi i osteoporoze, rizični su čimbenici dugotrajna terapija glukokortikoidima i bisfosfonatima, dugotrajan teži nedostatak vitamina D i osteomalacija, renalna osteodistrofija, primarni hiperparatiroidizam, Pagetova bolest, dugotrajna nepokretnost i radioterapija zbog maligne bolesti $(6,7)$.

Prijelomi sakruma u oslabljenoj kosti koji nastaju spontano, bez prethodne traume, često su neprepoznat uzrok lumbosakralne i zdjelične boli u starijoj dobi, posebice u starijih žena s osteoporozom (6). Specifični klinički znakovi ne postoje zbog čega se dijagnoza postavlja kasno, najčešće kao slučajan nalaz (8). Ovakvi 
made late, and they are most often revealed as an accidental finding (8). These fractures are often associated with degenerative diseases of the spine and intervertebral disc, and they are often accompanied by pre-existing osteoporotic vertebral compression fractures, which makes the diagnosis even more difficult (9). Plain radiographs of the spine and pelvis, which are the first step in diagnostic imaging, are usually non-diagnostic when it comes to sacral stress fractures $(10,11)$. Due to radicular pain symptoms caused by degenerative changes, magnetic resonance imaging (MRI) of the lumbosacral (LS) spine is the next step in diagnosis, in which sacral fractures are often revealed as accidental findings. MRI of the pelvis is the most sensitive test in the diagnosis of sacral fractures. Computerised tomography (CT) of the pelvis and bone scintigraphy are additional diagnostic methods.

Treatment is mainly conservative, especially when it comes to fatigue fractures (2). Surgical procedure is indicated if there is severe sacroiliac dysfunction and instability (2).

In recent times, sacroplasty is increasingly being used in the treatment of sacral fractures, as a minimally invasive procedure (12).

\section{CASE REPORT}

The patient M. L., a 77-year-old woman, was admitted to Clinical Hospital Centre Rijeka for an examination due to pain in her lower back and hips. The patient's medical history revealed that 5 months prior to this examination, the patient's plain radiographs of the LS spine showed vertebral compression fracture of the second lumbar vertebra (L2) without any previous trauma or fall. Due to end-stage renal disease, the patient was treated with chronic (long-term) haemodialysis for 4 years.

During the clinical examination, osteoporotic posture was evident, in the form of a short torso in relation to the extremities and a hunched posture. Kidney percussion came back positive. The patient was walking, by making small steps on a wide surface, without using any aids. The neurological status of the patient showed normal muscle strength in the patient's legs, with preserved reflexes and superficial sensation. The Oswestry Low Back Pain Disability Questionnaire, used for the measurement of the patient's functional disability, showed that the patient had severe functional disability, at the score of $57.7 \%$ (13).

Bone densitometry (DXA) findings showed osteoporosis with a measured T-value of -5.4 at the spine, at the vertebral level L1 - L4, and -3.0 at the left hip in total, which confirmed the diagnosis of severe osteoporosis with vertebral compression fracture of the second lumbar vertebra (L2). prijelomi često su udruženi s degenerativnim promjenama kralježnice i intervertebralnog diska te s osteoporotičnim prijelomima kralježaka, što dodatno otežava dijagnozu (9). Na standardnim radiogramima kralježnice i zdjelice, koji su prvi korak u slikovnoj dijagnostičkoj obradi, stresne frakture sakruma najčešće se ne uočavaju $(10,11)$. Zbog često prisutnih radikularnih simptoma uzrokovanih degenerativnim promjenama sljedeći dijagnostički korak jest magnetska rezonancija (MR) lumbosakralne (LS) kralježnice na kojoj su prijelomi sakruma najčešće slučajan nalaz. MR zdjelice najosjetljivija je pretraga u dijagnostici prijeloma sakruma. Kompjutorizirana tomografija (CT) zdjelice i scintigrafija kosti dodatne su dijagnostičke metode.

Liječenje je uglavnom konzervativno, posebice prijeloma zamora (2). Kirurški pristup indiciran je pri teškom instabilitetu sakruma (2).

U novije vrijeme sakroplastika kao minimalno invazivan postupak sve češće nalazi svoje mjesto u liječenju prijeloma sakruma (12).

\section{PRIKAZ BOLESNICE}

Bolesnica M. L., u dobi od 77 godina, došla je na pregled u KBC Rijeka zbog boli u križima i kukovima. Iz anamneze se saznalo da je prije 5 mjeseci na standardnim radiogramima LS kralježnice ustanovljen kompresivni prijelom trupa drugoga slabinskog (LII) kralješka bez prethodne traume ili pada. Zbog terminalne bubrežne bolesti bolesnica je otprije 4 godine bila na kroničnoj hemodijalizi.

Kliničkim pregledom bio je vidljiv osteoporotičan stav u obliku skraćenog trupa u odnosu prema ekstremitetima i pogrbljenog držanja. Lumbalna sukusija bila je pozitivna. Bolesnica je hodala sitnim koracima po širokoj osnovi bez pomagala. U neurološkom statusu mišićna je snaga na nogama bila uredna, uz očuvane vlastite reflekse i površinski osjet. Oswestryjski upitnik (engl. Oswestry Low Back Pain Disability Questionnaire) za procjenu funkcionalne nesposobnosti u bolesnika s križoboljom pokazao je tešku funkcionalnu onesposobljenost od 57,7\% (13).

Nalaz denzitometrije skeleta (DXA) pokazao je osteoporozu uz izmjerenu T-vrijednost od $-5,4$ na kralježnici LI - LIV i -3,0 na lijevom kuku ukupno, što je uz kompresivni prijelom trupa kralješka LII potvrdilo tešku osteoporozu.

Zbog kronične hemodijalize koju je nalagala terminalna bubrežna bolest liječenje osteoporoze u bolesnice bilo je ograničeno na nadomjesnu terapiju aktivnim oblikom vitamina $\mathrm{D}$ (kalcitriol). Bolesnica je uključena u program fizikalne terapije, ali nije došlo do smanjenja intenziteta boli, kao ni do poboljšanja funkcionalne sposobnosti mjerene oswestryjskim upitnikom za pro- 
Due to chronic (long-term) haemodialysis, which had to be done for the treatment of end-stage renal disease, the osteoporosis treatment in the case of this patient was limited to a replacement treatment with an active form of vitamin D (calcitriol). The patient was put on a physical therapy programme, but there was no improvement with regard to the reduction of pain intensity, nor was there any improvement in the patient's functional ability, measured by the Oswestry Low Back Pain Disability Questionnaire, so, for the aforementioned reasons, additional radiological tests were performed. Plain radiographs of the thoracic and lumbar spine showed no new vertebral fractures, but they have confirmed the diagnosis of vertebral compression fracture of the second lumbar vertebra (L2) (vertebral body compression corresponding to grade II according to the Genant classification of vertebral fractures) (Figure 1). Plain radiographs of the pelvis have shown degenerative changes in both coxofemoral joints with no other signs of pathological remodelling (Figure 2), and the superposition of bowel loops in the projection of the sacrum made it impossible to give a more precise analysis of the bony structure of the sacrum. Due to persistent pain, during further processing an MRI of the LS spine was performed, which showed advanced degenerative changes with neural foraminal stenosis and, with previously confirmed compression fracture of the lumbar vertebra L2 (grade II according to the Genant classification of vertebral fractures), as well as the fracture of the lumbar vertebra L4 (grade I according to the Genant classification of vertebral fractures) which occurred long before this examination. In addition to that, spondylolisthesis of L5 vertebra (grade I) was observed, caused by hypertrophic osteoarthropathy of the intervertebral joints at the same level. At the L3-L5 level, due to the rotation of the vertebra in the sagittal plane, the results of the plain radiographs gave the impression of spondylolisthesis of the L3 vertebra, but the anterior median line was not disturbed, which was confirmed by the MRI. An unexpected finding during the MRI was an extensive oedema of the spongy bone found in the lateral masses of the sacrum (Figure $3)$. In addition to the extensive oedema of the surrounding spongy bone (Figure 4), which was shown through the fat suppression technique, bilateral linear zones of low signal intensity were observed on the axial sections of the T1-weighted image. This kind of finding is typical for sacral stress fractures. Due to multiple comorbidities, the patient was treated with conservative methods of treatment, with an emphasis on bed rest. During the following two years, the patient went for regular check-ups. The patient has successfully completed another cycle of physical therapy, which included individual medical exercises, as well as electroanalgesia. The Oswestry Low Back Pain Disability

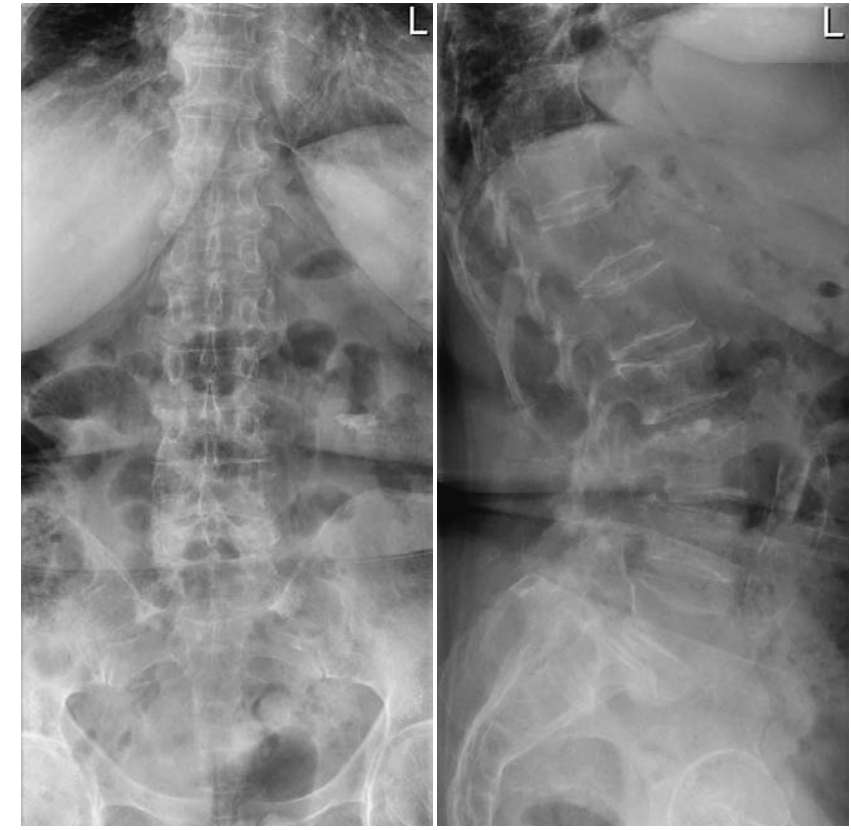

FIGURE 1. Radiographs of the LS spine showed vertebral compression fracture of the second lumbar vertebra (L2) (grade II according to the Genant classification of vertebral fractures) with diffuse degenerative changes, hypertrophic osteoarthropathy of intervertebral joints at the L3-S1 level, and signs of skeletal osteopenia.

SLIKA 1. Radiogrami LS kralježnice pokazuju kompresivnu frakturu kralješka L2 (2. stupnja prema Genantovoj klasifikaciji) uz difuzne degenerativne promjene, hipertrofični osteoartritis intervertebralnih zglobova u segmentima L3 - S1 te osteopeničnu strukturu kosti

cjenu funkcionalne nesposobnosti u bolesnika s križoboljom, zbog čega je dodatno učinjena radiološka obrada. Na standardnim radiogramima prsne i slabinske kralježnice nisu uočeni novonastali prijelomi kralježaka, uz potvrdu kompresivnog prijeloma trupa kralješka LII (smanjene visine trupa koji odgovara 2. stupnju prema Genantu) (slika 1.). Standardni radiogrami zdjelice pokazali su degenerativne promjene obaju koksofemoralnih zglobova bez drugih znakova patološke pregradnje (slika 2.), a superpozicija crijevnih vijuga u projekciji sakruma onemogućila je precizniju analizu koštane strukture sakruma. Zbog trajno prisutnih boli u daljnjoj obradi učinjen je MR lumbosakralne kralježnice, koji je pokazao uznapredovale degenerativne promjene sa suženjem neuralnih foramena te, uz prije potvrđen kompresivni prijelom trupa kralješka LII (2. stupanj prema Genantu), i prijelom trupa kralješka LIV (1. stupanj prema Genantu) starijeg datuma. Također, uočena je spondilolisteza kralješka LV 1. stupnja, uvjetovana hipertrofičnim osteoartritisom intervertebralnih zglobova $\mathrm{u}$ istom segmentu. U segmentu LIII - LIV, zbog rotacije kralježaka u frontalnoj ravnini, na standardnim se radiogramima stekao dojam listetičkog pomaka kralješka LIII, no prednja interkorporalna linija nije bila narušena, što je 
Questionnaire, used for the measurement of the patient's functional disability showed, that the patient's functional disability has improved, and that it was now at the score of $48.88 \%$.

\section{DISCUSSION}

Sacral insufficiency fractures can cause low back and pelvic pain which contribute to the debilitation of the patient. These fractures can occur spontaneously or due to small, underlying trauma. The occurrence of pain is usually acute. Pain is mechanical in nature, which means that is subsides when the patient is resting, and it becomes more intense when stress and strain are placed on the muscles (such as standing or walking), so in this case moving is usually significantly more difficult. In rare cases, the pain may be clearly localised in the sacral region. At times, patients may experience radicular symptoms in their legs. Therefore, it is difficult to diagnose a patient based on their medical history and clinical examination and the diagnosis is often made late or delayed (9).

Diagnosis is further complicated by the fact that sacral fractures are not usually shown on a plain radiograph of the lumbar spine and pelvis, and the fact that degenerative changes of the spine, osteoporosis and osteoporotic vertebral fractures are common findings, which can lead to misdiagnosis and complicate the diagnosis of sacral insufficiency fractures $(14,15)$.

When it comes to risk factors, the patient whose case is described in this case report had the factors of old age and severe osteoporosis with osteoporotic vertebral fractures as well as chronic end-stage renal disease due to which she had to be treated with haemodialysis. Low back pain was additionally caused by degenerative changes and instability of the lumbar spine. Considering the fact that the pain did not subside after the applied physical therapy, the patient was subjected to further diagnostic processing. Standard radiographic testing typically did not indicate a sacral fracture. However, what did indicate this was an accidental finding on the MRI of the LS spine. In the study conducted by Cabarrus et al., out of 108 insufficiency fractures in the pelvic region, which were detected with a pelvic MRI or LS spine MRI, only 16 (14.8\%) of those fractures were diagnosed by plain radiographs of the pelvis or LS spine, and only $3.8 \%$ (2 out of 53 ) of them were found to be sacral fractures. This fact clearly confirms that, in most cases, it is not possible to diagnose or rule out pelvic fractures, least of all fractures in the sacral area, through the use of plain radiographs. On a plain radiograph, the presence of a sclerotic line in the bone, a cortical rupture, or a visible fracture gap indicate an insufficiency fracture (15).

Sacral fractures, in addition to insufficiency fractures, are often experienced by athletes, as fatigue frac-

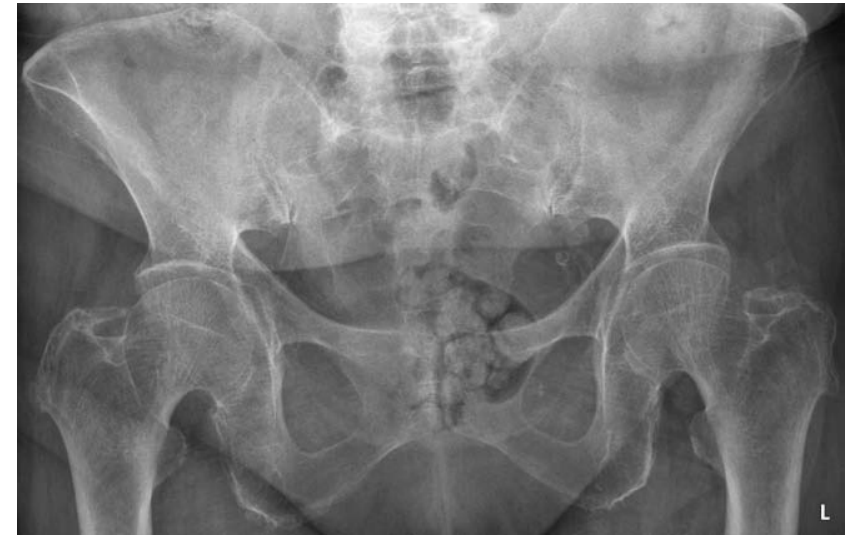

FIGURE 2. Plain radiograph of the pelvis showed signs of femoroacetabular impingement and bone spurs at the muscle attachments to the pelvic girdle.

SLIKA 2. Standardni radiogram zdjelice pokazuje znakove femoroacetabularnog sraza i koštana izvučenja na hvatištima tetiva zdjeličnog obruča

potvrdio i MR. Neočekivan nalaz na MR-u bio je opsežan edem spongioze lateralnih masa sakruma (slika 3.). $\mathrm{Na}$ aksijalnim presjecima u T1 mjerenoj slici uočene su obostrane linearne zone slabog intenziteta signala uz opsežan okolni edem spongioze kosti prikazan tehnikom supresije masti (slika 4.). Takav je nalaz tipičan za stresne prijelome sakruma. S obzirom na višestruke komorbiditete, bolesnica je konzervativno liječena $s$ naglaskom na mirovanju. Tijekom sljedeće dvije godine odlazila je na redovite kontrole. Proveden je još jedan ciklus fizikalne terapije koji je uključivao individualne medicinske vježbe, uz elektroanalgeziju, sa zadovoljavajućim uspjehom. Oswestryjski upitnik za procjenu funkcionalne nesposobnosti pokazao je sniženje stupnja funkcionalnog onesposobljenja, $\mathrm{s}$ vrijednosti od $48,88 \%$.

\section{RASPRAVA}

Prijelomi sakruma u oslabljenoj kosti mogu uzrokovati boli u donjem dijelu leđa i zdjelici koje onesposobljuju bolesnika. Mogu nastati spontano ili zbog vrlo male traume. Nastup boli najčešće je akutan. Bol je mehanička karaktera, tj. smanjuje se mirovanjem, a pojačava pri opterećenju (stajanje, hod), tako da je kretanje najčešće znatno otežano. Rjeđe bol može biti jasno lokalizirana u predjelu sakruma. Katkad bolesnici imaju radikularne simptome u nogama. Stoga se dijagnoza teško postavlja na osnovi anamneze i kliničkog pregleda te je često odgođena (9).

Postavljanje dijagnoze dodatno otežava činjenica da se prijelom sakruma najčešće ne prikazuje na standardnoj radiografskoj snimci slabinske kralježnice i zdjelice, a uobičajen su nalaz i degenerativne promjene kralježnice, osteoporoza i osteoporotični prijelomi kralježaka, što sve može voditi prema krivoj dijagnozi i 


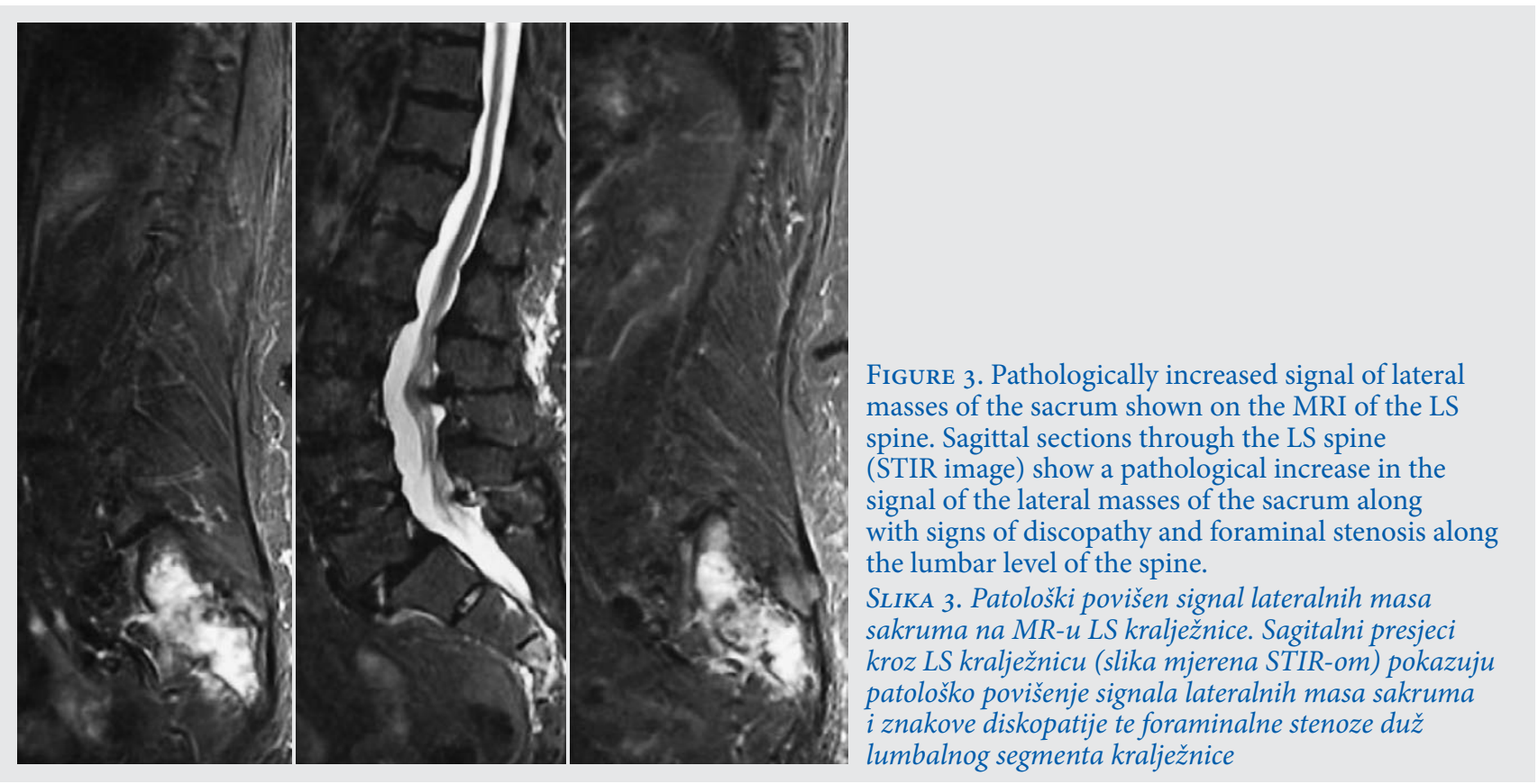

tures that occur due to stress that is placed on normal bone $(4,5,16)$. When it comes to insufficiency fractures in the pelvic area, in $70 \%$ of patients two or more fractures are present at the same time $(15,17,18)$. In $88 \%$ of patients, sacral fractures are associated with pubic rami fractures and / or parasymphyseal fractures (17), and somewhat less frequently, with acetabular fractures and fractures in the area of the wing (ala) of the ilium (18).

According to De Smet et al., there are initial changes in the sacrum with consequent mechanical stress on other pelvic bone structures (17).

Sacral fractures are also one of the possible complications after surgical stabilisation of the lumbar spine $(19,20)$. A sacral fracture associated with grade II spondylolisthesis at the L5-S1 level, caused by spondylolysis, which, most likely, occurred as a consequence of pathological anterior shear force, has also been described (21). Considering that sacral fracture is one of the possible complications after surgical stabilisation of the spine, and due to the low sensitivity of radiography, in elderly patients with spondylolisthesis for whom surgical treatment is planned, it is recommended to perform an MRI of the spine and the sacrum during preoperative preparation in order to exclude or confirm the underlying sacral insufficiency fracture $(19,21)$.

In everyday clinical work, and due to the often-present radicular symptoms caused by degenerative changes of the spine, the next diagnostic step, after plain radiographs, is the MRI $(9,22)$. This was also the case with the patient whose case is described in this case report. MRI of the pelvis shows almost 100\% sensitiv- otežati postavljanje dijagnoze prijeloma sakruma u oslabljenoj kosti $(14,15)$.

Bolesnica koju smo prikazale u ovom radu od rizičnih je čimbenika imala stariju dob i tešku osteoporozu s osteoporotičnim prijelomom kralješka te kroničnu bubrežnu bolest u terminalnoj fazi zbog čega je provedena hemodijaliza. Boli u donjem dijelu leđa dodatno su uzrokovale i degenerativne promjene te nestabilnost slabinske kralježnice. Budući da se nakon primijenjene fizikalne terapije bol nije smanjila, bolesnica je dodatno dijagnostički obrađena. Standardna radiografska obrada tipično nije upućivala na prijelom sakruma, nego je to bio slučajan nalaz na MR-u lumbosakralne kralježnice. U radu Cabarrusa i suradnika od 108 prijeloma u oslabljenoj kosti u području zdjelice, otkrivenih s pomoću MR-a zdjelice ili MR-a lumbosakralne kralježnice, na standardnim je radiogramima zdjelice ili lumbosakralne kralježnice dijagnosticirano samo njih $16(14,8 \%)$, a od toga tek 3,8\% (2/53) prijeloma sakruma. To jasno potvrđuje da standardni radiogrami najčešće ne mogu dijagnosticirati ni isključiti prijelom u području zdjelice, ponajmanje prijelom u području sakruma. Na standardnom radiogramu prisutnost sklerotične linije u kosti, prekid kortikalisa ili vidljiva frakturna pukotina upozoravaju na prijelom u oslabljenoj kosti (15).

Prijelomi sakruma, osim u oslabljenoj kosti, nastaju i u sportaša kao prijelomi zamora u zdravoj kosti zbog preopterećenja $(4,5,16)$. Kod prijeloma u oslabljenoj kosti u području zdjelice u $70 \%$ bolesnika prisutna su istodobno dva prijeloma ili je prisutno više njih $(15,17$, 18). U $88 \%$ bolesnika prijelomi sakruma udruženi su s prijelomima grana pubičnih kostiju i/ili parasimfizeal- 

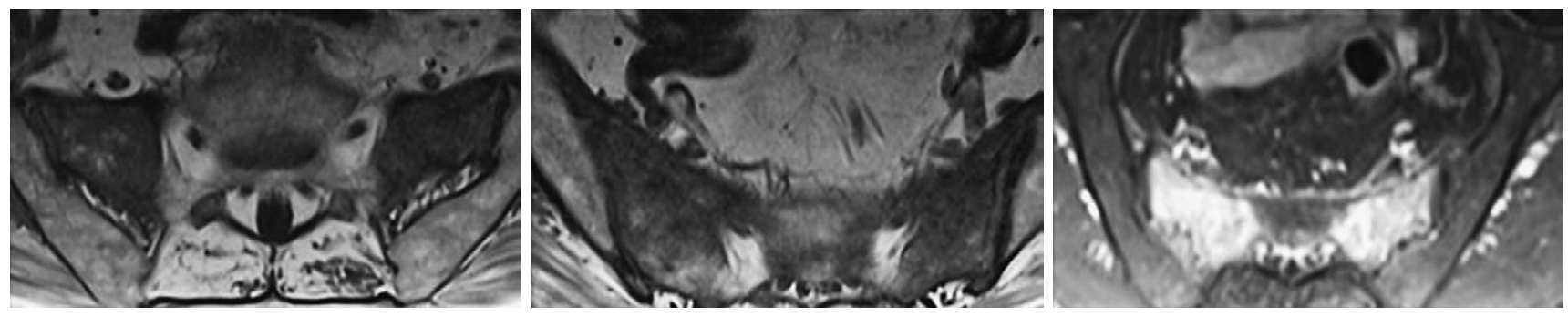

FiguRE 4. On the T1-weighted image, axial sections through the sacrum show linear zones of low signal intensity, which can be seen bilaterally in the areas extending through lateral masses of the sacrum and which correspond to fracture lines. The extensive high signal zones in the STIR image (last image on the right) correspond to the oedema of the surrounding spongy bone. No pathological changes of the SI joints were observed.

SLIKA 4. Transverzalni presjeci kroz sakrum obostrano u području lateralnih masa sakruma pokazuju linearne zone niskog signala u slici mjerenoj T1, koje odgovaraju frakturnim linijama. Opsežne zone visokog signala u slici mjerenoj slici STIR-om

(krajnje desna slika) odgovaraju edemu spongioze okolne kosti. SI zglobovi uredna su prikaza

ity during the detection of insufficiency fractures in the pelvic area and it showed better results in fracture detection than the CT scan. Cabarrus et al. state that, through the MRI, they have managed to detect 128 out of $129(99 \%)$ fractures in 63 of $64(98 \%)$ patients, while the CT scan revealed only 89 out of 129 (69\%) fractures in 34 of 64 (53\%) patients (15).

Typical signs of fracture that were visible on the MRI were bone marrow oedema and fracture gaps. Fracture gaps are most visible in sequences in T1 (spin-lattice) relaxation time. Bone marrow oedema is presented as a region of high intensity in sequences in T2 (spinspin) relaxation time with fat suppression and in STIR sequences, as well as a region of low intensity in sequences in $\mathrm{T} 1$ (spin-lattice) relaxation time in relation to the surrounding normal bone. MRI has an almost $100 \%$ sensitivity for detecting spongy bone oedema, but it is a relatively nonspecific sign present in various bone-related pathological conditions, ranging from reactive oedema due to mechanical stress, oedema related to postconcussional syndrome, to processes related to inflammation and tumours (15). During the interpretation of MRI findings, it should be taken into account that a fracture gap is not always visible and that diagnostic errors are possible, especially in patients with malignant diseases. However, in almost $90 \%$ of insufficiency fractures, bone marrow oedema and fracture gaps are present at the same time (15).

In the differential diagnosis, primary malignant disease or metastatic lesions in malignant disease and osteomyelitis are most often considered.

Sacral insufficiency fracture most commonly affects both sacral alae and is vertical in shape. The horizontal component, which usually passes through the vertebral body of the second sacral (S2) vertebra (22), is also common. Fractures are most visible on oblique coronal sections through the sacrum. The bone scintigraphy which utilizes technetium, shows a typical pattern of pathological accumulation of radiopharmaceuticals ne regije (17), a nešto rjeđe s prijelomima u području acetabuluma i krila crijevne kosti (18).

Prema De Smetu i suradnicima, inicijalne su promjene na sakrumu s posljedičnim mehaničkim preopterećenjem na ostalim zdjeličnim koštanim strukturama (17).

Prijelomi sakruma također su jedna od mogućih komplikacija poslije kirurške stabilizacije lumbalne kralježnice $(19,20)$. Opisan je i prijelom sakruma povezan sa spondilolistezom 2. stupnja segmenta LV - SI, uzrokovanom spondilolizom, a najvjerojatnije kao posljedica patološke anteriorne sile smicanja (21). Budući da je prijelom sakruma moguća komplikacija kirurške stabilizacije kralježnice, a s obzirom na nisku osjetljivost radiografije, u starijih bolesnika sa spondilolistezom kod kojih se planira kirurško liječenje preporučuje se tijekom preoperativne pripreme učiniti MR kralježnice i sakruma te tako isključiti ili eventualno potvrditi podležeći prijelom sakruma u strukturalno oslabljenoj kosti $(19,21)$.

U svakodnevnom kliničkom radu, a zbog često prisutnih radikularnih simptoma uzrokovanih degenerativnim promjenama kralježnice, nakon standardnih radiograma sljedeći dijagnostički korak jest MR (9, 22). Tako je bilo i u bolesnice koju prikazujemo. MR zdjelice pokazuje gotovo $100 \%$-tnu osjetljivost pri otkrivanju prijeloma u oslabljenoj kosti u području zdjelice te nadmašuje CT. Cabarrus i suradnici navode da su s pomoću MR-a otkrili 128 od 129 (99\%) prijeloma u 63 od 64 (98\%) bolesnika, dok je primjenom CT-a otkriveno samo 89 od 129 (69\%) prijeloma u 34 od 64 (53\%) bolesnika (15).

Tipični znakovi prijeloma vidljivi na MR-u jesu edem kosti i frakturna pukotina. Ona se najbolje prikazuje na sekvencijama u mjernom vremenu T1. Edem kosti prikazuje se kao područje visokog intenziteta na sekvencijama u mjernom vremenu T2 sa supresijom masti i na sekvencijama STIR te kao područje smanjenog intenziteta na sekvencijama u mjernom vremenu $\mathrm{T} 1 \mathrm{u}$ odnosu prema okolnoj normalnoj kosti. MR ima gotovo stopo- 
(on the posterior scan) in the shape of the letter $\mathrm{H}$ (the so-called $\mathrm{H}$ sign, the Honda sign or the butterfly sign). In other words, two vertical lines in the area of the sacral alae connected by a horizontal line are shown. It should be noted that, sometimes, the accumulation pattern may be incomplete, e.g., if one vertical component is missing. The sensitivity of scintigraphy in detecting sacral insufficiency fractures is very high (96\%), with a positive predictive value of $92 \%$ (23).

Although the CT scan has a lower sensitivity than the MRI (between 60 and 75\%), this radiological technique can also help to distinguish between insufficiency fractures and malignant bone remodelling, due to a better presentation of cortical destruction, and a clearer picture of possible fracture gap spread, as well as the neural foraminal stenosis affected areas, which is especially important when planning treatment with the sacroplasty procedure $(15,24)$.

On the other hand, in comparison to the CT scan, the MRI is significantly better in detecting lesions of soft tissue structures. In sacral fractures, oedema of the surrounding soft tissue is less common (in $36 \%$ of cases) than in pubic bone fractures (65\% of cases) or acetabular fractures (64\% of cases), as well as the proximal part of the femur (51\% of cases) (15).

Cabarrus et al. showed that soft tissue lesions on the MRI were detected in $99 \%$ of patients compared to only $12.6 \%$ of these lesions that were visible on the CT scan (15). It should be noted that both methods are significantly better at detecting acetabular and sacral fractures compared to plain radiography $(15,25)$.

Sacral insufficiency fracture treatment is mostly treated with conservative methods of treatment. The usual approach to treatment includes bed rest during the course of 3 to 6 months, which causes accelerated bone mineral density (BMD) loss. Other unwanted complications for people who are on prolonged bed rest (and immobilised) include thromboembolism and the occurrence of decubitus ulcers with secondary infections (26).

Early mobilisation, on the other hand, stimulates osteoblast activity and new bone formation. Weightbearing exercises and hydrotherapy are standard methods during rehabilitation (27). Pain management is important in the treatment of sacral insufficiency fractures. Non-steroidal anti-inflammatory drugs (NSAIDs) are widely used, but they should be used with caution, as some studies indicate that such drugs may lead to bone mineral density loss and that they can slow down fracture healing by disrupting endochondral ossification $(28,29)$. Treatment with paravertebral injections with an oxygen-ozone mixture has also shown encouraging results in the treatment of opioid-resistant pain (30). stotnu osjetljivost za detekciju edema spongiozne kosti, no to je relativno nespecifičan znak koji je prisutan kod različitih patoloških stanja što zahvaćaju kost, počevši od reaktivnog edema zbog mehaničkog preopterećenja, postkontuzijskog edema do upalnih i tumorskih procesa (15). Tijekom interpretacije nalaza MR-a treba uzeti u obzir da frakturna pukotina nije uvijek vidljiva te su moguće dijagnostičke pogreške posebice $\mathrm{u}$ bolesnika s malignim bolestima. Ipak, u gotovo $90 \%$ prijeloma u oslabljenoj kosti istodobno su prisutni edem kosti i frakturna pukotina (15).

U diferencijalnoj dijagnozi najčešće $u$ obzir dolaze primarna maligna bolest ili metastatske lezije kod maligne bolesti te osteomijelitis.

Prijelom sakruma u oslabljenoj kosti najčešće zahvaća oba krila i vertikalnog je oblika. Česta je i horizontalna komponenta koja obično prolazi trupom drugoga sakralnog (SII) kralješka (22). Prijelomi su najvidljiviji na kosim koronalnim presjecima kroz sakrum. Na scintigrafiji skeleta tehnecijem vidi se tipičan obrazac patološkog nakupljanja radiofarmaka (na posteriornom skenu) $u$ obliku slova $H$ (tzv. znak $H$ ili znak Honda ili znak leptira), tj. prikazuju se dvije vertikalne linije u području krila sakruma spojene horizontalnom linijom. Treba naglasiti da katkad obrazac nakupljanja može biti nepotpun, npr., ako nedostaje jedna vertikalna komponenta. Osjetljivost scintigrafije pri otkrivanju prijeloma sakruma u oslabljenoj kosti veoma je visoka (96\%-tna), s pozitivnom prediktivnom vrijednosti od $92 \%$ (23).

Iako CT ima manju osjetljivost od MR-a (između 60 i $75 \%$ ), i ta radiološka tehnika može pomoći pri razlikovanju prijeloma u oslabljenoj kosti i maligne pregradnje kosti, i to zbog boljeg prikaza destrukcije kortikalisa, a jasniji je i prikaz eventualnog širenja frakturne pukotine i zahvaćanja neuralnih foramena, što je osobito važno pri planiranju liječenja metodom sakroplastike $(15,24)$.

$\mathrm{S}$ druge strane, MR je u usporedbi s CT-om znatno bolji pri detekciji lezija mekotkivnih struktura. Kod prijeloma sakruma edem okolnoga mekog tkiva rjeđe je prisutan (u 36\%) nego kod prijeloma u području pubičnih kosti (65\%) ili acetabuluma (64\%), kao i proksimalnog dijela femura (51\%) (15).

Cabarrus i suradnici pokazali su da su lezije mekih tkiva na MR-u prepoznate u $99 \%$ bolesnika u usporedbi s njih tek $12,6 \%$ vidljivih na CT-u (15). Valja naglasiti da su obje metode znatno bolje u detekciji prijeloma acetabuluma i sakruma u usporedbi sa standardnom radiografijom $(15,25)$.

Liječenje prijeloma sakruma u oslabljenoj kosti uglavnom je konzervativno. Uobičajen pristup jest mirovanje tijekom 3 - 6 mjeseci, što dovodi do ubrzanoga gubitka mineralne gustoće kosti. Neželjene komplikacije dugotrajnog mirovanja jesu i trombo- 
In recent times, sacroplasty is increasingly being used in the treatment of sacral stress fractures, as a minimally invasive procedure. It is intended to rapidly relieve the symptoms of clinical conditions, primarily pain, which allows early mobilisation of such patients (12). Vertebroplasty is a technique based on injecting polymethyl methacrylate (PMMA) cement into the fracture gap area. The two biggest challenges of this technique are safe needle insertion and safe cement extrusion. Cement injection into the sacrum was originally used to treat painful skeletal metastases, and twenty years ago it was first performed in the treatment of osteoporotic fractures of the sacrum (31).

There are several ways of performing sacroplasty, which differ primarily in terms of the method of approach and the insertion of the needle. A posterior approach is typically used when, through the use of fluoroscopy or, less commonly, a CT scan, an 11- or 13-gauge bone biopsy needle is inserted percutaneously through the sacral cortex, in a plane parallel to the SI (sacroiliac) joint. When using the approach along the longitudinal axis, the needle is inserted in the caudocranial direction, along the sacral Y-axis (the longitudinal axis of the sacrum). The mediosagittal approach requires a postoperative magnetic resonance imaging, due to the fact that the needle passes through the central canal of the sacrum, so it is necessary to confirm that the tip of the needle is located more to the caudal end than the distal end of the thecal sac. The occurrence of complications in sacroplasty are rare. The highest risk is that of cement leakage outside the fracture gap into the sacral foramina and spinal canal. Neuritis of the sacral spinal nerve 1 (S1) has been described as a consequence of cement migration after sacroplasty (32). Cement leakage into the paraspinal soft tissues holds no major clinical significance. As with vertebroplasty, complications of venous thromboembolism and nerve damage are possible $(32,33)$. Given the importance of fracture gap localisation and extension for a satisfactory sacroplasty outcome, Gesa Bakker, et al. have proposed a classification of sacral fractures, divided into 3 groups: (i) group A includes fractures that have no mechanical importance and fractures with no cortical disruption, (ii) group B is formed by complete fractures of the sacral alae, starting in the anterior cortical bone or fractures which affect the neural foramina and the sacral canal, and (iii) group C includes fractures in the sacral corpus with fracture lines continuing to the anterior or posterior cortical bone or the sacral foramina (24).

Several other methods for the treatment of sacral fractures have been described, such as balloon-assisted sacroplasty, kyphoplasty, or transiliosacral screw insertion fluoroscopic techniques, but in clinical practice embolijska bolest te razvoj dekubitusa sa sekundarnim infekcijama (26).

Rana mobilizacija, s druge strane, potiče aktivnost osteoblasta i stvaranje nove kosti. Vježbe opterećenja i hidroterapija standardne su metode tijekom rehabilitacije (27). Kontrola boli važna je u liječenju prijeloma sakruma u oslabljenoj kosti. Nesteroidni protuupalni lijekovi u širokoj su uporabi, no potreban je oprez s obzirom na to da pojedine studije navode kako takvi lijekovi mogu smanjiti mineralnu gustoću kosti te usporavaju cijeljenje prijeloma narušavajući enhondralno okoštavanje $(28,29)$. Ohrabrujuće rezultate u liječenju boli rezistentne na opioide pokazalo je i liječenje paravertebralnim injekcijama mješavine kisika i ozona (30).

U novije vrijeme sakroplastika kao minimalno invazivan postupak sve češće nalazi svoje mjesto u liječenju stresnih prijeloma sakruma. Namijenjena je brzom olakšavanju kliničkih tegoba, ponajprije boli, što omogućava ranu mobilizaciju takvih bolesnika (12). Vertebroplastika je tehnika koja se temelji na injiciranju polimetilmetakrilatnog (PMMA) cementa u područje frakturne pukotine. Dva najveća izazova ove tehnike jesu sigurno uvođenje igle i sigurna ekstruzija cementa. Injekcija cementa u sakrum prvotno se rabila za liječenje bolnih koštanih rasadnica (metastaza), a prije dvadesetak godina prvi je put izvedena radi liječenja osteoporotičnog prijeloma sakruma (31).

Više je načina izvođenja sakroplastike koji se razlikuju ponajprije $s$ obzirom na način pristupa i uvođenje igle. Tipično se rabi stražnji pristup kada se pod kontrolom fluoroskopije ili rjeđe CT-a perkutano kroz sakralni korteks, u ravnini paralelnoj sa SI zglobom, uvodi igla za biopsije kosti od 11 ili 13 G. Kod pristupa po uzdužnoj osi igla se uvodi u kaudokranijalnom smjeru duž longitudinalne osi sakruma. Mediosagitalni pristup nalaže postproceduralni slikovni prikaz magnetskom rezonancijom budući da igla prolazi centralnim kanalom sakruma pa je potrebno potvrditi da se vrh igle nalazi kaudalnije od distalnog kraja duralne vreće. Komplikacije sakroplastike rijetke su. Najviši je rizik od curenja cementa izvan frakturne pukotine u sakralne foramene i spinalni kanal. Opisan je neuritis živca S1 kao posljedica migracije cementa poslije sakroplastike (32). Curenje cementa u paraspinalna meka tkiva bez većeg je kliničkog značenja. Kao i kod vertebroplastike, moguće su komplikacije venska embolija i neuralna oštećenja $(32,33)$. S obzirom na važnost lokalizacije i ekstenzije frakturne pukotine za zadovoljavajući ishod sakroplastike, Gesa Bakker sa suradnicima predložila je klasifikaciju prijeloma sakruma u 3 grupe: (i) grupa A obuhvaća prijelome bez mehaničkog značenja koji ne zahvaćaju kortikalis, (ii) grupu B čine potpuni prijelomi krila sakruma s prekidom anteriornog kortikalisa ili koji zahvaćaju neuralne foramene i sakralni kanal, (iii) 
these methods have not been increasingly implemented so far $(34-36)$.

Surgical methods of treatment are indicated in patients in whom conservative methods of treatment have not yielded any positive results. The challenge of surgical treatment is to achieve satisfactory stability in an already structurally weakened bone. By performing stabilisation using transiliac-transsacral screws, mobility is achieved in a significant number of patients with a satisfactory effect on the absence of pain (37). Better interfragmentary compression is achieved through the placement of a transsacral plate (38). Iliosacral screw fixation ((ISS) is a commonly used treatment method, but some studies have shown that through this method satisfactory mechanical stability is not achieved, which leads to displacement and instability of the screws (39). Lumbosacral fixation technique is indicated in patients with neurological complications due to unstable sacral fractures (40).

\section{CONCLUSION}

Sacral insufficiency fractures which occur in the structurally weakened bone are often overlooked causes of nonspecific lumbosacral back pain, especially in elderly women with underlying osteoporosis. Plain radiographs of the pelvis are often non-diagnostic when it comes to this type of fractures, and the diagnostic imaging method of choice is MRI, which is also confirmed in our case report. Inflammation or malignant disease must first be excluded through the process of differential diagnosis. Treatment is mainly performed through conservative methods, and in recent times, sacroplasty is increasingly being used in the treatment of sacral fractures, as a minimally invasive procedure.

Conflict of interest statement: Authors declare no conflict of interest. grupa C obuhvaća prijelome korpusa sakruma s povišenjem prema anteriornom ili posteriornom korteksu ili sakralnim foramenima (24).

Opisano je još nekoliko metoda za liječenje prijeloma sakruma poput sakroplastike s balonom, kifoplastike ili fluoroskopskog postavljanja transiliosakralnih vijaka, ali u kliničkoj praksi te metode dosad nisu znatnije zaživjele $(34-36)$.

Kirurške metode liječenja indicirane su u pacijenata kod kojih konzervativno liječenje nije dalo rezultata. Izazov kirurškog liječenja jest postići zadovoljavajuću stabilnost u već strukturalno oslabljenoj kosti. Stabilizacijom s pomoću transilijakalno-transsakralnih vijaka postiže se mobilnost u znatnog broja bolesnika uz zadovoljavajući učinak na izostanak boli (37). Bolja interfragmentarna kompresija postiže se postavljanjem transsakralne ploče (38). Iliosakralna fiksacija vijcima često je upotrebljavana metoda liječenja, no neka su istraživanja pokazala da se ovom metodom ne postiže zadovoljavajuća mehanička stabilnost, što dovodi do pomicanja i nestabilnosti vijaka (39). Lumbosakralna fiksacija indicirana je u bolesnika s neurološkim komplikacijama zbog nestabilnog prijeloma sakruma (40).

\section{ZAKLJUČAK}

Prijelomi sakruma u strukturalno oslabljenoj kosti često su neprepoznat uzrok lumbalne i zdjelične boli bez prethodne traume, osobito u žena starije dobi s osteoporozom. Na standardnim radiogramima zdjelice ovi se prijelomi rijetko uočavaju, a dijagnostička metoda izbora jest MR, što je potvrđeno i u našem prikazu bolesnice. Diferencijalno dijagnostički ponajprije treba isključiti upalni ili maligni proces. Liječenje je uglavnom konzervativno, a u novije vrijeme sakroplastika kao minimalno invazivan postupak sve češće nalazi svoje mjesto pri liječenju prijeloma sakruma $u$ oslabljenoj kosti.

IZjAVA o sukobu interesa: Autori izjavljuju da nisu u sukobu interesa. 


\section{REFERENCES / LITERATURA}

1. Pentecost RL, Murray RA, Brindley HH. Fatigue, insufficiency, and pathologic fractures. Jama. 1964;187:1001-4.

2. Santolini E, Kanakaris NK, Giannoudis PV. Sacral fractures: issues, challenges, solutions. EFORT Open Rev. 2020;5:299-311.

3. Longhino V, Bonora C, Sansone V. The management of sacral stress fractures: current concepts. Clin Cases Miner Bone Metab. 2011;8(3):19-23.

4. Vajapey S, Matic G, Hartz C, Miller TL. Sacral Stress Fractures: A Rare but Curable Cause of Back Pain in Athletes. Sports Health. 2019;11(5):446-52.

5. Hosey R, Fernandez M, Johnson D. Evaluation and Management of Stress Fractures of the Pelvis and Sacrum. Orthopedics. 2008;31:383-5.

6. Mattila VM, Niva M, Kiuru M, Pihlajamaki H. Risk factors for bone stress injuries: a follow-up study of 102,515 person-years. Med Sci Sports Exerc. 2007;39:1061-6.

7. Ayanaoğlu T, Atik OŞ, Tokgöz N, Uçar M. Sacral and pubic insufficiency fractures due to bisphosphonate treatment. Eklem Hastalik Cerrahisi. 2015;26(2):120-4.

8. Grasland A, Pouchot J, Mathieu A, Paycha F, Vinceneux P. Sacral insufficiency fractures: an easily overlooked cause of back pain in elederly women. Arch Intern Med. 1996;156: 668-74.

9. Sudhir G, Kalra KL, Shankar A, Chahal R. Sacral insufficiency fractures mimicking lumbar spine pathology. Asian Spine J. 2016;10:558-64.

10. Gotis-Graham I, McGuigan L, Diamond T i sur. Sacral insufficiency fractures in the elderly. J Bone Joint Surg Br. 1994;76: 882-6.

11. Finiels H, Finiels PJ, Jacquot JM, Strubel D. Fractures of the sacrum caused by bone insufficiency: meta-analysis of 508 cases. Presse Med. 1997;26:1568-73.

12. Bayley E, Srinivas S, Boszczyk BM. Clinical outcomes of sacroplasty in sacral insufficiency fractures: a review of the literature. Eur Spine J. 2009;18:1266-7.

13. Fairbank JC, Pynsent PB. The Oswestry Disability Index. Spine (Phila Pa 1976). 2000;25(22):2940-52.

14. Spiegl UJA, Schnake KJ, Osterhoff G i sur. Imaging of Sacral Stress and Insufficiency Fractures. Z Orthop Unfall. 2019; 157(2):144-53.

15. Cabarrus MC, Ambekar A, Lu Y, Link TM. MRI and CT of insufficiency fractures of the pelvis and the proximal femur. AJR Am J Roentgenol. 2008;191:995-1001.

16. Miletić D, Šestan B, Pusić M, Cicvarić T, Tudor A, Roth S, Šantić V. Unusual consecutive sacral stress fractures in a female distant runner: a case report. Eur J Phys Rehabil Med. 2012; 48(2):283-7.

17. De Smet AA, Neff JR. Pubic and sacral insufficiency fractures: clinical course and radiologic findings. AJR Am J Roentgenol. 1985;145:601-6.

18. Grangier C, Garcia J, Howarth NR, May M, Rossier P. Role of MRI in the diagnosis of insufficiency fractures of the sacrum and acetabular roof. Skeletal Radiol. 1997;26:517-24.

19. Scemama C, D’astorg H, Guigui P. Sacral stress fracture after lumbar and lumbosacral fusion. How to manage it? A proposition based on three cases and literature review. Orthop Traumatol Surg Res. 2016;102:261-8.

20. Asad A, Junaid J, Hashmi I. Sacral insufficiency fracture, a rare complication of posterior spinal instrumentation. J Pak Med Assoc. 2019;69:1380-2.
21. Schizas C, Theumann N. An unusual natural history of a L5-S1 spondylolisthesis presenting with a sacral insufficiency fracture. Eur Spine J. 2006;15(4):506-9.

22. Kim YY, Chung BM, Kim WT. Lumbar spine MRI versus nonlumbar imaging modalities in the diagnosis of sacral insufficiency fracture: a retrospective observational study. BMC Musculoskelet Disord_2018;19:257.

23. Fujii M, Abe K, Hayashi $\mathrm{K}$ i sur. Honda sign and variants in patients suspected of having a sacral insufficiency fracture. Clin Nucl Med. 2005;30:165-9.

24. Bakker G, Hattingen J, Stuetzer H, Isenberg J. Sacral Insufficiency Fractures: How to Classify? J Korean Neurosurg Soc. 2018;61:258-66.

25. Kinoshita H, Miyakoshi N, Kobayashi T, Abe T, Kikuchi K, Shimada Y. Comparison of patients with diagnosed and suspected sacral insufficiency fractures. J Orthop Sci. 2019;24:702-7.

26. Parry SM, Puthucheary ZA. The impact of extended bed rest on the musculoskeletal system in the critical care environment. Extrem Physiol Med. 2015;4:16.

27. Urits I, Orhurhu V, Callan J i sur. Sacral Insufficiency Fractures: a Review of Risk Factors, Clinical Presentation, and Management. Curr Pain Headache Rep. 2020;24(3):10.

28. Su B, O'Connor JP. NSAID therapy effects on healing of bone, tendon, and the enthesis. J Appl Physiol. 2013;115:892-9.

29. García-Martínez O, De Luna-Bertos E, Ramos-Torrecillas J, Manzano-Moreno FJ, Ruiz C. Repercussions of NSAIDS drugs on bone tissue: the osteoblast. Life Sci. 2015;123:72-7.

30. De Sire A, Baricich A, Minetto MA, Cisari C, Invernizzi M. Low back pain related to a sacral insufficiency fracture: role of paravertebral oxygen-ozone therapy in a paradigmatic case of nociplastic pain. Funct Neurol. 2019;34:119-22.

31. Garant M. Sacroplasty: a new treatment for sacral insufficiency fracture. J Vasc Interv Radiol. 2002;13:1265-7.

32. Frey ME, Depalma MJ, Cifu DX, Bhagia SM, Carne W, Daitch JS. Percutaneous sacroplasty for osteoporotic sacral insufficiency fractures: a prospective, multicenter, observational pilot study. Spine J. 2008;8:367-73.

33. Pommersheim W, Huang-Hellinger F, Baker M, Morris P. Sacroplasty: A Treatment for Sacral Insufficiency Fractures. AJNR Am J Neuroradiol. 2003;24:1003-7.

34. Atalay B, Caner H, Yilmaz C, Altinors N. Sacral kyphoplasty for relieving pain caused by sacral hemangioma. Spinal Cord. 2006;44:196-9.

35. Deen H, Nottmeier EW. Balloon kyphoplasty for treatment of sacral insufficiency fractures. Neruosurg Focus. 2005;18(3):e7.

36. Scuibba DM, Wolinsky JP, Than KD, Gokaslan ZL, Witham TF, Murphy KP. CT fluoroscopically guided percutaneous placement of transiliosacral rod for sacral insufficiency fracture: case report and technique. AJNR Am J Neuroradiol. 2007;28: 1451-4.

37. Walker JB, Mitchell SM, Karr SD, Lowe JA, Jones CB. Percutaneous transiliac-transsacral screw fixation of sacral fragility fractures improves pain, ambulation, and rate of disposition to home. J Orthop Trauma. 2018;32:452-6.

38. Mehling I, Hessmann MH, Rommens PM. Stabilization of fatigue fractures of the dorsal pelvis with a trans-sacral bar. Operative technique and outcome. Injury. 2012;43:446-51.

39. Oberkircher L, Masaeli A, Bliemel C, Debus F, Ruchholtz S, Krüger A. Primary stability of three different iliosacral screw fixation techniques in osteoporotic cadaver specimens - a biomechanical investigation. Spine J. 2016;16:226-32.

40. Maki S, Nakamura K, Yamauchi T i sur. Lumbopelvic fixation for sacral insufficiency fracture presenting with sphincter dysfunction. Case Rep Orthop. 2019;2019:1-4. 